\author{
F. M. Issatayeva ${ }^{1}$, \\ orcid.org/0000-0001-6208-3292, \\ G. I. Rudko², Dr. Sc. (Geol.-Miner.), Dr. Sc. (Geogr.), \\ Dr. Sc. (Tech.), Prof., \\ orcid.org/0000-0001-7752-4310, \\ V.S. Portnov', Dr. Sc. (Tech.), Prof., \\ orcid.org/0000-0002-4940-3156
}

\title{
TECHNICAL AND ECONOMIC SUBSTANTIATION OF DEVELOPING KUSMURYN COPPER DEPOSIT (KAZAKHSTAN)
}

Purpose. Substantiation of an economically feasible method for developing the Kusmuryn deposit.

Methodology. Analysis of literature and stock materials; studying physical and mechanical properties of rocks and ores.

Findings. To improve economic performance and to reduce the cost of concentrate at the Kusmuryn deposit, the mining system is being changed. To replace the chamber-and-pillar development system, which allows extracting all the available reserves, a more effective model was introduced: development of inter-chamber pillars with a high metal content. The authors proved the expediency of development by the open method using the development system with horizontal layers with the goaf stowing.

Originality. Calculating the technical and economic indicators of the three mining options allowed selecting the most effective mining method at the Kusmuryn deposit. In order to prevent underground fires, a layer caving system with siltation of crushed rocks is recommended. For disseminated ores, the usual method with collapsing overlying rocks is applicable.

Practical value. Based on the studies, recommendations were developed for the Kazakhmys Corporation. They are referred to reducing the open pit mining at the Kusmuryn field in 2019. This stabilizes the achieved production level and compensates for retiring functioning facilities associated with the field. The introduction of underground mining is recommended from 2021.

Keywords: mineral resource base, copper ore, Kusmuryn deposit, reserves, KAZRC, CRIRSCO

Introduction. Kazakhstan possesses huge reserves of copper ore, ranking seventh in the world in copper mining, $92 \%$ of which is exported abroad (Fig. 1). The main industrial types of ores are copper sandstones (71\%) and porphyry copper (24\%).

In Kazakhstan there are 7.621 deposits, of which 3.362 are in subsoil use, 3.817 are reserves. The total number of gold deposits is 343 (reserves: 2.4 thousand tons), silver: 196 (50.7 thousand tons), copper: 125 (40 million tons), chromium: 17 (355 million tons), nickel: 41 (2 million tons) [1].

In the medium term, the leading international company for extracting and processing natural resources, the largest copper producer in Kazakhstan, the Kazakhmys Corporation LLP focuses on geological exploration of mineral resources carried out as part of a comprehensive development plan for the cities of Zhezkazgan and Satpayev [2, 3]. Zhezkazgan is the largest ore deposit of copper sandstones.

In the development of the Karagayli production complex in 2018-2020 the Kazakhmys Corporation LLP plans to invest 16 billion tenges: to complete construction and put into operation the mines at the gold and copper deposits of Akbastau ( 2 million tons with the content of $1.69 \%$ ) and Kusmuryn (1.5 million tons with the average content of $3.15 \%$ ). There are projects planned for the construction of new mines, an innovative project for the hydrometallurgical treatment of crude copper concentrate of Zhezkazgan ores, the construction of a concentration mill and additional exploration of the Akbastau-Kusmuryn ore field in order to detect deposits of copper, gold, poly-metals and other minerals. In 2019-2026 it is planned to produce 301.7 million tons of ore with the average copper content of $0.98 \%$. By 2022 due to exploration work at five deposits, including the Kusmuryn deposit, it is planned to increase the output of cathode copper to 300 thousand tons, by 2025 ore production should amount to 5265 thousand tons, stripping 52901 thousand $\mathrm{m}^{3}$.

The Kazakhmys Corporation is actively carrying out geological exploration in all regions of its presence: Zhezkazgan, Karaganda, Balkhash and East Kazakhstan. In the areas where prospecting is carried out both to identify new copper ore objects and in the existing deposits, up-to-date geophysical technologies are used: electrical exploration methods TDIP and AMT + MT that allow solving a wide range of tasks in search-

(C) Issatayeva F. M., Rudko G. I., Portnov V. S., 2019 ing and exploration of various types of deposits. The use of integrated approaches helps to identify signs of ore objects at great depths and to increase reliability of the prediction of hidden and poorly manifested mineralization.

At present the issues of selecting a cost-effective way of developing the Kusmuryn deposit in the coming years are being updated. The need to improve economic indicators, to reduce the cost of concentrate, and to change the mining system is taken into account. The foregoing determined the selection of the research topic $[4,5]$.

Literature review. The formation of a new management system requires rethinking the existing methodological approaches to the economic feasibility of exploration work, forming the principles and methods of geological and economic assessment of deposits, taking into account modern economic theory and formation of a competent environment $[6,7]$. Currently, the mandatory factors of geological and economic assessment of deposits include: the source of investment and financing conditions, the rate of return, the lifetime of the enterprise, the taxation system, the principle of achieving the maximum economic effect of the project [8]. The net discounted income $[9,10]$ takes the leading place.

Given the growing strategic importance of the mining and metallurgical complex to boost the economy of Kazakhstan, it is planned to enter previously unknown markets with the subsequent geographical expansion of supply [11, 12]. Sectoral improvement will be based on increasing the mineral resource base, deepening the integrated processing of raw materials, increasing reliability of the geological and economic assessment of deposits [13].

The introduction of the CRIRSCO international system of reporting standards for mineral reserves will contribute to increasing the investment attractiveness of the mineral resource complex of Kazakhstan, guaranteeing investors that the information provided to them is the most reliable and truthful [14].

The state provides support in digitizing the materials of the geological industry with the upholding of national interests, where it is objectively necessary: the single map of the country's geological exploration, the transition to intellectual deposits, technology transfer [15]. The experience in digitizing the fields of Embamunaigas JSC, an oil company engaged in exploration, development of oil and gas fields, production and 


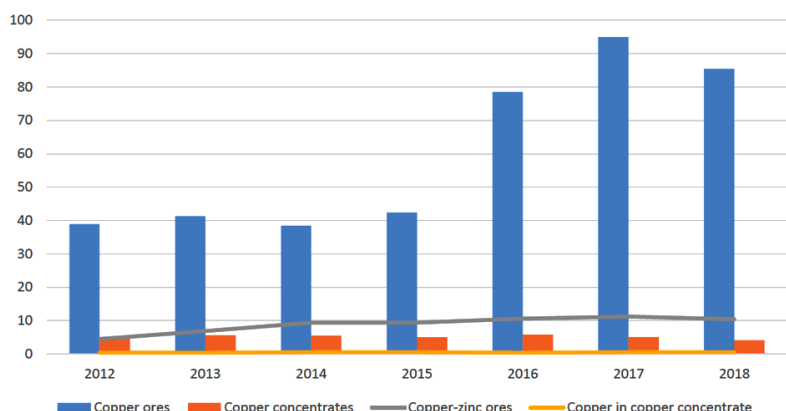

Fig. 1 Mining ores and copper concentrates in Kazakhstan, million ton

preparation of oil and gas, indicates that digitizing small fields with a small number of wells can save about 50-70 million tenges. For 2018-2019 it is planned to digitize the materials from about 10-20 fields, including the Kusmuryn field.

The steps taken are an example of the state, systematic approach to the development of our own industrial base in the medium and long term in order to ensure sustainable and balanced economic growth through diversification and internationalization of actions characteristic of developing economic systems [16, 17].

Unsolved aspects of the problem. Today in Kazakhstan the increase in mineral reserves depends on the existing exploratory backlog. On the one hand, this leads to significant increase in the share of reserves already explored and prepared for further development in the general structure of reserves. On the other hand, it helps to reduce the share of estimated reserves and various types of resources calculated in forecasts.

Kazakhstan is striving to meet the international requirements for stock assessment. In particular, taking into account the fact that if earlier there was allowed calculating the content of the main produced element at the early and intermediate research stages, now the emphasis is on the information obtained from the results of semi-industrial tests. There is also taken into account a new standard of engineering design that involves the risk control from the standpoint of the socio-economic and environmental results of the project. Preliminary calculation of geological reserves, knowledge of technological studies, indicators of capital costs, the costs of the main and associated products lay the basis for calculating commercial ore reserves. In the future, based on marketing research and price forecasts, profitability of the ore content at the mine is estimated.

Purpose. Substantiation of the economically feasible way of mining the Kusmuryn deposit.

Tasks: to justify the economic inconsistency of developing the deposit by the open method using the development system with horizontal layers with the goaf stowing; to identify the most effective way to develop the deposit based on the analysis of the results of technical and economic indicators of three options for transporting rock from the open pit, to develop recommendations for the Kazakhmys corporation for selecting a method of the further development of the deposit.

Methods. The pyrite-copper-lead-zinc deposit Kusmuryn studied back in the Soviet period, with an enormous potential, is currently the subject of exploratory research as part of the state assignment to study promising areas for attracting investments. The genesis of the deposit is combined, expressed in the combination of volcanogenic sedimentary and hydrothermal metasomatic ore formation. The deposit is mainly represented by the Upper ore body and the Main ore zone, within which three main ore bodies are distinguished: I, II and III. The ore bodies are accompanied by several small ore lenses (more than 5 pcs.).

The shape of the ore bodies is lenticular, the angles of incidence are $40-70^{\circ}$ to the west, southwest, the dimensions are from 95 to $580 \mathrm{~m}$ to the dip and from 50 to $330 \mathrm{~m}$ in the strike, with the thickness from 0.6 to $70-100 \mathrm{~m}$. The main ore minerals are: pyrite, chalopyrite, sphalerite, and galena. In the mixed and hypogene ores, the reserves (by categories $C_{1}, C_{2}$ ) of copper, zinc, lead, gold, silver, sulfur, selenium, tellurium, and cadmium were calculated [14].

The exploration work at the field was carried out in 1958-1976, 1977-1980 (detailed searches). In 2006-2008 the Kusmuryn field was mined by the open method, in 2010-2012 exploratory and appraisal drilling was carried out, the exploration work (additional exploration) was carried out (Figs. 2, 3).

The balance reserves distribution was approved by the State Commission for Mineral Reserves of the Republic of Kazakhstan, by the exploration categories: $\mathrm{C}_{1}$ exploration category $(90 \%)-250.6$ thousand tons and $\mathrm{C}_{2}$ exploration category $(10 \%)-52.9$ thousand. tons.

The Kazakhmys Corporation LLP, which obtained the right to perform the mining of polymetallic ores at the deposit, developed it as open-pit (aero-photo of the Kusmuryn deposit, Fig. 4).

The deposit became the key raw material source of copper and copper-zinc ore for the Karagailinsky concentrator, which is a part of the corporation.

In 2009, due to prevailing mining and geological conditions and decreasing the volume of available raw materials, the corporation decided to reorganize production:

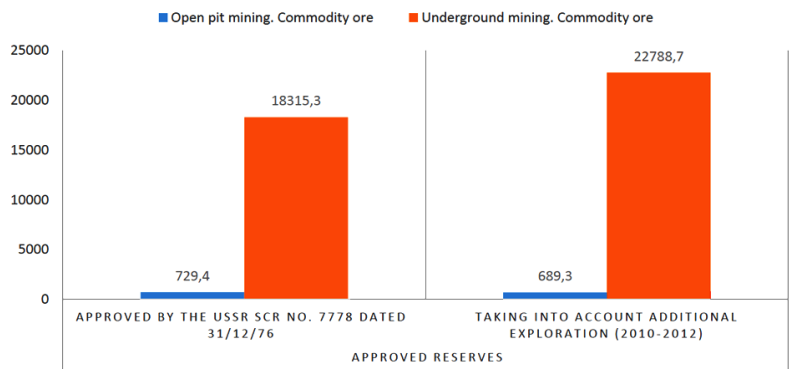

Fig. 2. The Kusmuryn deposit reserves

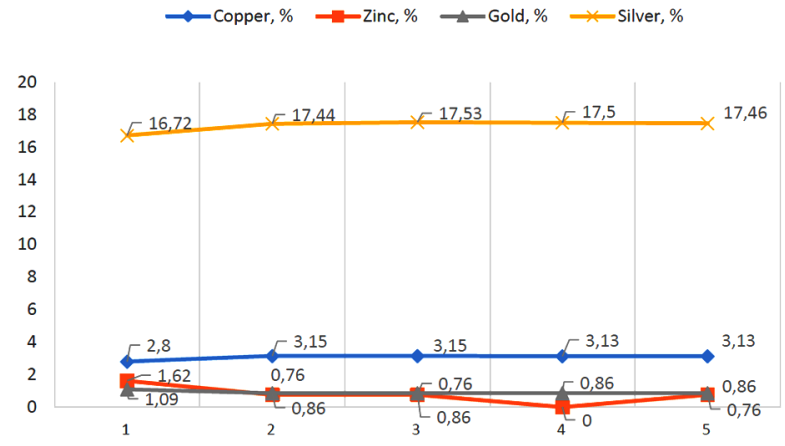

Fig. 3. Balance reserves distribution approved by the Republic of Kazakhstan SCR, at horizons:

$1-600 ; 2-500 ; 3-400 ; 4-300 ; 5-200$

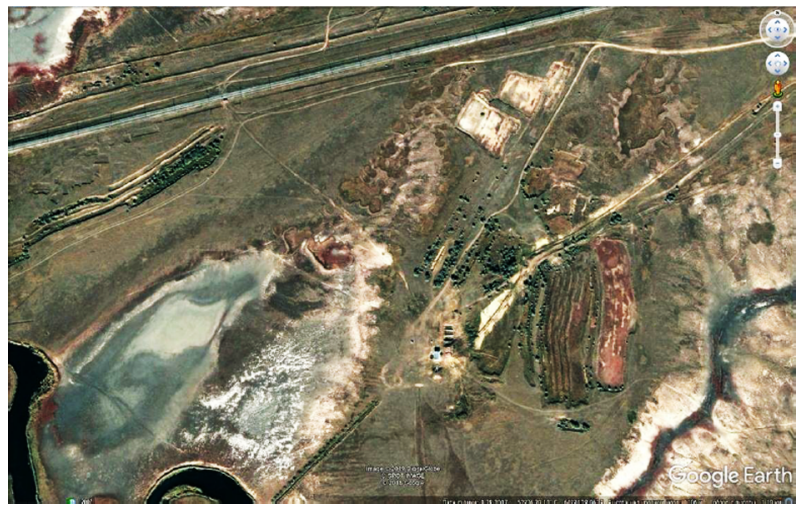

Fig. 4. Aero-photo of the Kusmuryn deposit 
- Zhezkazgan smelter was transferred to the operation mode of one ore-thermal furnace, the second melting unit was completely mothballed;

- production was reduced from 1045 thousand tons to 176 thousand tons with preservation of the funds for social development of the region and training Kazakhstani specialists;

- until 2012 production was suspended;

- an improved technological scheme for treating copperzinc ores was developed on the basis of a representative technological sample with additional financing for exploration in the amount of $\$ 4$ million.

In 2010-2012 there was performed technological sampling, additional exploration of the flanks of the field and engineering-geological drilling with determining the physical and mechanical properties of the rocks to determine stability of the sides during deepening the open pit.

In 2013 the project of industrial development of the Kusmuryn deposit by underground method was implemented.

In 2014 copper treatment decreased by $16.3 \%$ due to modernization of the Zhezkazgan Mining and Metallurgical Complex, and the project "Additional development of the Kusmuryn Open Pit Reserves" was implemented.

In total, in the course of geological exploration as on 01/01/1976 there were drilled 41.700 r.m of prospecting and exploratory wells in the field, in 1977-1980 there were drilled 11 wells with the volume of 7640 r.m, in 2010-2012 there were drilled 26 wells with the volume of 13006 running meters, in 2016 there were drilled 6 small wells in the open pit contour and two laboratory technological samples were taken [17, 18].

According to the results of 2016-2017, a feasibility study was completed. In 2016 the additionally explored reserves were not put on the balance sheet for accounting by the State Commission on Mineral Reserves of the Republic of Kazakhstan.

The head design institute of the Kazakhmys Corporation LLP calculated the increase in reserves based on the block model of reserves, and in 2018, taking into account the data obtained we evaluated several options for developing the reserves of the Kusmuryn deposit (Table 1) [18].
The development of the field reserves by the underground method with the mining period of 25 years was adopted as the basic option. This option was considered according to the stripping scheme: with driving the "Ventilation" shaft $650 \mathrm{~m}$ deep according to the project and with driving the transport incline from the side of the projected open pit and the lifting riser $(400 \mathrm{~m})$ (Tables 2 and 3$)$

In the second option, for which implementing the technological equipment is planned (8 SBSh-250 MN drilling machines, 9 EKG-10 excavators, 961 SAT 777 dump trucks), the mining of the field reserves by the open method to the depth of $660 \mathrm{~m}$ with the mining life of 29 years was considered (Table 3 ).

The calculations show the economic inconsistency of opencast mining using the development system with horizontal layers with the goaf stowing (Tables 4, 5). The indicators of open pit mining in this option are improved compared to the second option due to decreasing the volume of stripping operations.

In order to improve technical and economic indicators, several versions of the rock mass transportation from the open pit were considered: by auto-mobile or conveyor transport, by the inclined skip.

The analysis of the results of technical and economic indicators (Table 6) of all three options shows that the underground mining method is effective, since the main reserves of poly-metal ores are concentrated below the $600 \mathrm{~m}$ horizon. Therefore, with the open mining method, there is needed a significant volume of stripping operations. The stripping ratio is $14.8-22.0 \mathrm{~m}^{3} / \mathrm{t}$, and with the annual ore productivity of 1.0 million tons, the open pit mine productivity will range from 13.0 to 22.2 million $\mathrm{m}^{3}$ per year. And finally, as the pit deepens, the length of the transportation of rock mass increases $(7-10 \mathrm{~km})$, which will increase the cost of ore mining.

In order to reduce the cost of ore transportation, when evaluating mining options, we considered several types inside the open pit transport: troilers, inclined skips and conveyors. However, due to the transportation of significant volumes of the rock mass, a positive efficiency is not achieved. Thus, open pit mining is inefficient.

Table 1

Reserves according to the basic option

\begin{tabular}{|c|c|c|c|c|c|c|c|}
\hline \multirow{3}{*}{ Name } & \multirow{3}{*}{ Unit } & \multicolumn{3}{|c|}{ Reserves approved by the USSR SCR No. 7778 dated 31/12/76 } & \multicolumn{3}{|c|}{ Reserves taking into account additional exploration } \\
\hline & & \multicolumn{2}{|c|}{ Mining operations } & \multirow{2}{*}{ total } & \multicolumn{2}{|c|}{ Mining operations } & \multirow{2}{*}{ total } \\
\hline & & open & underground & & open & underground & \\
\hline Ore & Th.t & 683.8 & 17572.7 & 18256.5 & 646.2 & 21771.4 & 22417.6 \\
\hline Ore losses & $\%$ & 4 & 3.6 & - & 4.0 & 3.6 & - \\
\hline Ore dilution & $\%$ & 10 & 7.9 & - & 10.0 & 7.9 & - \\
\hline
\end{tabular}

Table 2

Technical and economic indicators according to the basic option

\begin{tabular}{|c|c|c|c|c|c|c|c|}
\hline \multirow{3}{*}{ Indicators } & \multirow{3}{*}{ Units } & \multicolumn{3}{|c|}{ Approved by the SCR mineral reserves } & \multicolumn{3}{|c|}{ Reserves taking into account additional exploration } \\
\hline & & \multicolumn{2}{|c|}{ Mining operations } & \multirow[b]{2}{*}{ total } & \multicolumn{2}{|c|}{ Mining operations } & \multirow[b]{2}{*}{ total } \\
\hline & & $\begin{array}{l}\text { Underground } \\
\text { from } 2019\end{array}$ & $\begin{array}{l}\text { Open from } \\
2022\end{array}$ & & $\begin{array}{l}\text { Underground } \\
\text { from } 2019\end{array}$ & $\begin{array}{l}\text { Open from } \\
2022\end{array}$ & \\
\hline $\begin{array}{l}\text { Construction and } \\
\text { mining period }\end{array}$ & years & 23 & 4 & 27 & 25 & 4 & 29 \\
\hline Commodity ore & Th.t & 18315 & 729 & 19045 & 22789 & 689 & 23478 \\
\hline Stripping ratio & $\mathrm{m}^{3} / \mathrm{t}$ & - & 9.4 & 9.4 & - & 11.5 & 11.5 \\
\hline $\begin{array}{l}\text { Income from the sale } \\
\text { of marketable products: }\end{array}$ & Th.doll. & 3215700 & 136254 & 3351953 & 3827454 & 144849 & 3972304 \\
\hline Production profit & Th.doll. & 276267 & 28095 & 304362 & 236859 & 33222 & 270081 \\
\hline Expansion capital costs & Th.doll. & 255373 & 2385 & 257758 & 255376 & 2385 & 257761 \\
\hline Free cash flow & Th.doll. & 256387 & 26695 & 283082 & 222979 & 31822 & 2545801 \\
\hline Net present value & Th.doll. & 15685 & 11982 & 27637 & 13259 & 14026 & 27286 \\
\hline Internal rate of return & $\%$ & 14 & $>12$ & $>12$ & 14 & $>12$ & $>12$ \\
\hline Payback period & years & 13 & 1 & 7 & 13 & 1 & 7 \\
\hline
\end{tabular}


Technical and economic indicators according to the second option. Open mining operations (660 m depth)

\begin{tabular}{|l|l|c|}
\hline \multicolumn{1}{|c|}{ Name } & \multicolumn{1}{c|}{ Unit } & Value \\
\hline Additional exploration reserves: & Th.t & 22436.9 \\
\hline - commercial products & $\mathrm{t}$ & 662920 \\
\cline { 2 - 3 } & $\%$ & 2.95 \\
\hline Ore losses & $\%$ & 4.0 \\
\hline Ore dilution & $\%$ & 10.0 \\
\hline Commodity ore & Th.t & 23932.7 \\
\hline Ore performance & Th.t $/$ year & 1000 \\
\hline Rock capacity & $\mathrm{m}^{3} . \mathrm{m} / \mathrm{year}$ & 20000 \\
\hline Stripping ratio & $\mathrm{m}^{3} / \mathrm{t}$ & 22.0 \\
\hline $\begin{array}{l}\text { Income from the sale of marketable } \\
\text { products }\end{array}$ & Th.doll. & 67433 \\
\hline Production profit & & \\
\hline Capital expansion expenditures & Th.doll. & -2744534 \\
\hline Cash flow & Th.doll. & 40929 \\
\hline Net present value & Th.doll. & -2760283 \\
\hline
\end{tabular}

Table 4

Reserves according to the third option

\begin{tabular}{|l|l|c|c|c|}
\hline \multirow{4}{*}{ Name } & \multirow{3}{*}{} & \multirow{3}{*}{ Unit } & \multicolumn{3}{|c|}{$\begin{array}{l}\text { Open mining operations (420 m depth), } \\
\text { underground operations (200 m depth) }\end{array}$} \\
\cline { 3 - 4 } & & \multicolumn{3}{|c|}{$\begin{array}{c}\text { Reserves considering additional } \\
\text { exploration }\end{array}$} \\
\cline { 3 - 4 } & & Mining operations & \multirow{2}{*}{ total } \\
\cline { 3 - 4 } & Th.t & 13083.4 & 9353.5 & 22436.9 \\
\hline Ore & $\%$ & 4.0 & 3.0 & - \\
\hline Ore losses & $\%$ & 10.0 & 6.5 & - \\
\hline Ore dilution & $\%$ & 13955.6 & 9703.6 & 23659.3 \\
\hline Commodity ore & Th.t & \multicolumn{4}{|c}{} \\
\hline
\end{tabular}

In order to improve economic indicators and to reduce the cost of concentrate at the Kusmuryn deposit, the mining system was changed. To replace the chamber-and-pillar development system that makes it possible to extract all the available reserves, a more efficient model was introduced: the development of inter-chamber pillars with a high metal content.

Thus, as the most economical option, open cast mining of only the Upper ore body is recognized, studied with the use of boreholes in exploratory lines IIa, III, IIIa, IV, IVa and completely contoured by underground horizontal workings from mine No. 1 at $+750 \mathrm{~m}$ horizon (the depth from the surface $70 \mathrm{~m}$ ). In this case, the stripping ratio will be $10-15 \mathrm{~m}^{3} / \mathrm{t}$.

Of the total balance reserves of mixed ores calculated by categories $\mathrm{C}_{1}$ and $\mathrm{C}_{2}$, the ore reserves contained in the Upper
Technical and economic indicators according to the third option

\begin{tabular}{|l|l|c|c|c|}
\hline \multirow{2}{*}{ Indicators } & \multirow{2}{*}{ Unit } & \multicolumn{2}{c|}{ Mining operations } & \multirow{2}{*}{ total } \\
\cline { 3 - 4 } & & open & underground & \\
\hline Commodity ore & Th.t & 13956 & 9704 & 23659 \\
\hline Stripping ratio & $\mathrm{m}^{3} / \mathrm{t}$ & 14.8 & - & 14.8 \\
\hline $\begin{array}{l}\text { Income from the } \\
\text { sale of marketable } \\
\text { products }\end{array}$ & Th.doll. & 2560538 & 1321660 & 3881598 \\
\hline Operating costs & Th.doll. & 2388811 & 1863985 & 4252795 \\
\hline Production profit & Th.doll. & 125714 & -572130 & -446417 \\
\hline $\begin{array}{l}\text { Expansion } \\
\text { Capital Costs }\end{array}$ & Th.doll. & 75092 & 148518 & 223610 \\
\hline Free cash flow & Th.doll. & 107004 & -589624 & -482620 \\
\hline Net present value & Th.doll. & -18541 & -47104 & -65645 \\
\hline
\end{tabular}

ore body made $93 \%$. In the balance ore reserves calculated for the $\mathrm{C}_{1}$ category and approved by the USSR State Commission for Mineral Reserves in 1976, the ore reserves of the Upper ore body made $14 \%$.

According to the 2016 studies, the reserves in the Upper ore body amounted to: ore -2203.2 thousand tons, copper 94.8 thousand tons $(4.3 \%)$, zinc -52 tons $(2.36 \%)$, gold $6040 \mathrm{~kg}(2.74 \mathrm{~g} / \mathrm{t})$, silver -67.9 tons $(30.82 \mathrm{~g} / \mathrm{t})$. Ore reserves in the ore body are $6.1 \%$ relative to the total reserves of the deposit, copper reserves being $9.8 \%$, zinc $-22.5 \%$, gold $21.9 \%$, silver $-12.8 \%$. The foregoing indicates rich ore, especially for zinc and noble metals.

The remaining ore bodies can be mined underground. The tendency of solid ores to spontaneous combustion obliges to mine them with the measures that prevent occurrence of underground fires. For this purpose, it is recommended to develop the field with the layer-breaking system with siltation of the crushed rocks. Disseminated ores can be mined in the usual way with the collapse of the overlying rocks.

The calculations performed were recommended to the Kazakhmys Corporation and can prove useful in continuing to search the western and southern flanks of the Kusmuryn deposit, evaluating promising ore occurrences in the area of the field, and performing appraisal work by drilling core wells.

In general, the calculations show that in order to stabilize the achieved production level and compensate for retiring functioning facilities associated with the Kusmuryn deposit, the Kazakhmys Corporation should reduce open pit mining from 2019 and from 2021 to start underground mining.

Research development. Today Kazakhstan is solving one of the most difficult tasks of replenishing its mineral resources base, identifying promising geological exploration sites, new ore objects, and predicted mineral resources, assessing the pros-

Table 6

Technical and economic indicators of the options compared

\begin{tabular}{|c|c|c|c|c|c|}
\hline \multirow[b]{2}{*}{ Indicator } & \multirow[b]{2}{*}{ Unit } & \multicolumn{2}{|c|}{ Option 1 (underground mining operations) } & \multirow{2}{*}{$\begin{array}{c}\text { Option } 2 \\
\text { (open cast mining) }\end{array}$} & \multirow{2}{*}{$\begin{array}{c}\text { Option } 3 \\
\text { (open and underground } \\
\text { mining operations) }\end{array}$} \\
\hline & & $\begin{array}{l}\text { With driving the } \\
\text { ventilation shaft }\end{array}$ & $\begin{array}{l}\text { With driving a transport } \\
\text { incline and lifting riser }\end{array}$ & & \\
\hline $\begin{array}{l}\text { Cost of cathode copper with } \\
\text { associated components }\end{array}$ & doll./t & 5391 & 5352 & 10543 & 6677 \\
\hline Capital expenditures & Mln. doll. & 250.6 & 226.8 & 40.9 & 223.6 \\
\hline Net present value & Mln. doll. & 46.0 & 67.9 & -497.6 & -65.6 \\
\hline Internal rate of return & $\%$ & 14 & 17 & - & - \\
\hline Payback period & years & 7 & 6 & - & - \\
\hline
\end{tabular}


pects for identifying rare-earth metals deposits in the main ore provinces. In 2018 alone there were given 8 billion tenges from the republican budget for geological exploration of the subsoil of 78 objects. Private subsoil users also make a great contribution to solving this issue, their investments in geological exploration amounted to 177 billion tenges in 2017 and 180 billion tenges in 2018, at this $70 \%$ of them for oil and gas sector.

Within the framework of the import substitution policy, one of the tools to support local producers is the preferential mode, under which conditional discounts reach up to $20 \%$, and extends to metallurgy. So, goods are purchased from one source for subsoil users of the mining sector, if the local content in such a product is at least half, for subsoil users of the oil and gas sector - at least $65 \%$. It is possible to conclude long-term contracts for the period of up to 10 years, increasing the delivery time of goods. These support measures are provided for the procurement of national companies and government procurement [18].

The work is underway to improve industry legislation: the deadlines for submitting subsoil use rights were shortened, in accordance with the implemented "first come, first get" principle, 85 thousand blocks have been put in place, the applications for obtaining an exploration license have been started. A program for managing the state subsoil fund has been adopted, free access to geological information has been provided, and the transition to KAZRC standards corresponding to the international CRIRSCO system has been envisaged. The KAZRC Kazakhstan Code of Public Reporting meets the CRIRSCO requirements, includes the minimum requirements generally accepted in the global mining and geological community for reports on geology based on the results of geological exploration, mineral resources and reserves submitted by the companies to international investors, banks and exchanges. This opens up the possibility of entering the number of the international standards with subsequent worldwide recognition. With the entry into force of the new code, the procedure for submitting an application and obtaining a subsoil use right will change dramatically. The exhibited objects for obtaining licenses must be included in the program for managing the state subsoil fund.

In accordance with the mandatory requirements for the transition to the KAZRC international reporting standards on the results of geological exploration and reserves, in the coming years Kazakhstan plans to organize a commercial geochemical laboratory with international certification. At the moment the ALS Kazgeochemistry LLP is working, which was organized jointly with one of the world leading companies in the field of technical services: the ALS Limited Company, Austria.

By 2020 it is planned to form an information system "National Databank of Mineral Resources", combining and updating all historical geological data in a new format [15]. With its help, transparency of the activities of state bodies and subsoil users will be achieved. In order to attract investors to the mining industry, their access to registration of subsoil use rights and reporting was simplified.

Implementation of the public-private partnership instruments will stimulate private investment in implementation of projects for geological exploration of mineral resources, carrying out the most risky geological surveys, which will activate the advancement of innovative technologies in exploration work, accelerate the transition to international reporting standards for reserves [18].

For 2020-2030 it is planned to carry out prospecting and evaluation exploration activities, discovering new deposits and calculating mineral resources, ensuring expedient subsoil consumption in the studied areas, and continuing regional and prospecting work in new territories.

\section{Conclusions:}

1. The use of the development system with horizontal layers with the goaf stowing confirmed the economic inexpediency of developing the Kusmuryn field by open pit mining.

2. The comparative analysis of the technical and economic indicators of various options of transporting the rock mass from the open pit confirmed the most effective option for open pit mining of the Upper ore body only.

3. The Kazakhmys Corporation gave recommendations on selecting the method for further development of the field while reducing open pit mining and a gradual transition to underground mining, as economically more effective in the medium term.

4. To develop a program for attracting private subsoil users and local producers for the development of mining and geological operations at the Kusmuryn deposit and adjacent territories by developing measures to implement long-term contracts for performing the work, purchasing equipment and goods, and selling commodity ore, industrial product for copper and related elements.

5. To introduce the development program for mining and geological works at the Kusmuryn field, taking into account the KAZRC standard, to attract investments from state and private companies.

6. To develop a plan for organizing an up-to-date open geochemical laboratory in accordance with international standards.

7. Based on digitalization of mining and geological results for the entire period starting from the discovery of the Kusmuryn field, to form an information system for the effective development of the field and its planned development based on availability of the materials for all subsoil users in order to expand public-private partnerships, to develop innovative technologies with the purpose of ensuring current and future reserves growth, effective ore mass production and extraction of copper and related elements.

8. The promotion of innovative technologies into exploration will accelerate the transition to international reporting standards for reserves.

\section{References.}

1. Speech by the Chairman of the Committee of Geology and Subsoil Use of the Ministry of Investment and Development of the Republic of Kazakhstan at the World Mining Congress. Astana, June 20, 2018. Retrieved from https://www.amm.kz/ru/presstsentr/press-relizy/749-27-06-2018wmc-pr.

2. Dang, N. L. (2018). Comparative characteristics of singleindustry towns of Russia and Kazakhstan in the oil and gas industry. In Problems of geology and subsoil development: proceedings of the XXII International Symposium named after academician M. A. Usov of students and young scientists dedicated to the $155^{\text {th }}$ anniversary of the birth of academician V.A. Obruchev, the $135^{\text {th }}$ birthday of academician M.A. Usov, the founders of the Siberian Mining and Geological School, and the 110 anniversary of the first graduation of mining engineers in Siberia: in 2 volumes. Volume 2 (pp. 748-749). Tomsk: TPU Publishing House. Retrieved from http://earchive.tpu.ru/bitstream/ 11683/51229/1/conference tpu-2018-C11 V2 p748-749.pdf. 3. Decree of the Government of the Republic of Kazakhstan dated June 28, 2014 No. 728. On approval of the Regional Development Program until 2020 (as amended on June 17, 2015). Retrieved from https: //hcsbk.kz >download.

4. Wegera, S.G., \& Romanova, O.S. (2017). Accounting and analysis of mineral resources in the context of the concept of natural capital: a monograph. Butvapolotsk: Polotsk state. Univ. Retrieved from http://elib.psu.by:8080/handle/123456789/21193. 5. Singh, V., Yemez, I., Izaguirre, E., \& Racero, A. (2017). Optimal Subsurface Appraisal: A Key Link to the Success of Development Projects-Few Examples. American Journal of Applied Sciences, 14(2), 217-230.

6. Fadeichev, A. V., Kosolapov, O. V., \& Tseitlin, E. M. (2015). Improving the substantiation of conditions in the geological and economic assessment of deposits. Izv. Ural state. mountain university, 3(39), 47-52

7. Kubarev, M.S., \& Ignat'eva, M. N. (2018). Environmentally friendly nature management as one of the main conditions for sustainable development. News of the Ural State Mining University, (1), 94-100. https://doi.org/10.21440/23072091-2018-1-94-100. 
8. Podkorytov, V. N., \& Mochalova, L. A. (2019). Determination of the discount rate for the conditions of enter-prises of the mineral resources sector: argumentative issues. Izv. Uralskogos. Mining Univ., 2(54), 121-125.

9. Rudko, G.I., Dudinov, V.O., Burdeinyi, T.O., Maiborda, Ye. I., Lahoda, O.A., \& Tsibulskaya, O. V. (2013). Geological and economic assessment of the families of cinnamon kopalin, an indicator of the effectiveness of investment projects. Vidavnychyi dim "Bukrek".

10. Government of the Republic of Kazakhstan (2016). Forecast of socio-economic development of the Republic of Kazakhstan for 2017-2021. Approved at a meeting of the Government of the Republic of Kazakhstan (Minutes No. 29 of August 31, 2016). 11. Freiman, G. G. (2015, November 26-27). Prospects and problems of implementing international standards for assessing mineral resources and reserves in Kazakhstan. Materials of the international scientific-practical conference: geology, mineralogy and prospects for the development of mineral resources of the Republic of Kazakhstan, dedicated to the $75^{\text {th }}$ anniversary of the Institute of Geological Sciences. K. I. Satpayev. Almaty. Retrieved from http://ponen.kz/download/files/statya_o konvertacii_zapasov_gkz_freiman.pdf.

12. The State Program "Digital Kazakhstan". Approved by the Decree of the Government of the Republic of Kazakhstan dated December 12, 2017 No. 827.

13. Sanders, W. G., \& Carpenter, M.A. (2017). Internationalization and firm governance. Academy of Management Journal, 41(2). https://doi.org/10.5465/257100.

14. Nalbandyan, G. G. (2019). Internationalization strategies of Russian non-energy companies. Strategic decisions and risk management, (1), 36-45. https://doi.org/10.17747/2618947X-2019-1-36-45.

15. Rudko, G. I., Myatchenko, A. V., Portnov, V. S., \& Isataeva, F. M. (2018). Geological and economic valuation of stocks of deposits of Kazakhstan. Sustainable development of mining territories, 10(4(38)), 471-480. https://doi.org/10.21177/19984502-2018-10-4-471-480.

16. Rudko, G. I., Portnov, V. S., \& Issatayeva, F. M. (2018). Geological and economic valuation of mineral reserves of Kazakhstan: international aspect. Industry of Kazakhstan, 3(104), 35-39. 17. The Republic of Kazakhstan Government Decree dated December 29, 2007 No. 1353 "On determining measures of state support for categories of domestic potential suppliers". Retrieved from https://online.zakon.kz/document/?doc id=3015173.

18. The Republic of Kazakhstan Code "On Subsoil and Subsoil Use" (with amendments and additions dated 05.24.2018). Retrieved from http://miid.gov.kz/ru/pages/kodeks-respubliki-kazahstan-o-nedrah-i-nedropolzovanii.

\section{Техніко-економічне обгрунтування відпрацювання міднорудного родовища Кусмурин (Казахстан)}

\section{Ф. М. Iсатаєва ${ }^{1}$, Г. І. Рудько ${ }^{2}$, В. С. Портнов ${ }^{1}$}

1 - Карагандинський державний технічний університет, м. Караганда, Республіка Казахстан, e-mail: isataeva. farida@gmail.com

2 - Державна комісія України по запасах корисних копалин, м. Київ, Україна, e-mail: rudko@dkz.gov.ua

Мета. Обгрунтування економічно доцільного способу відпрацювання родовища Кусмурин.

Методика. Аналіз літературних і фондових матеріалів; дослідження фізико-механічних властивостей порід і руд.

Результати. Для поліпшення економічних показників, зниження собівартості концентрату на родовищі Кусмурин змінюється система відпрацювання. На зміну камерно-стовповій системі розробки, що дозволяє витягувати всі наявні запаси, запроваджена більше ефективна модель - відпрацювання міжкамерних ціликів з високим вмістом металу. Авторами доведена доцільність відпрацювання відкритим способом з використанням системи розробки горизонтальними шарами та із закладкою.

Наукова новизна. Методика техніко-економічних показників трьох варіантів відпрацювання дозволила вибрати найбільш ефективний спосіб відпрацювання на родовищі Кусмурин. Із метою превентивних заходів, що запобігають підземним пожежам, рекомендовано систему шарового обвалення із замуленням порід, що порушуються. Для вкраплених руд застосуємо звичайний спосіб з обваленням налягають порід.

Практична значимість. На основі проведених досліджень розроблені рекомендації для корпорації „Казахмис“. Вони стосуються зменшення з 2019 року проведення відкритих гірничих робіт на родовищі Кусмурин. Це стабілізує досягнутий рівень видобутку, компенсує функціонуючі об’єкти, що вибувають, пов'язані із родовищем. Уведення підземного видобутку рекомендоване з 2021 року.

Ключові слова: мінерально-сировинна база, мідна руда, родовище Кусмурин, запаси, KAZRC, CRIRSCO

\section{Технико-экономическое обоснование отработки меднорудного месторождения Кусмурын (Казахстан)}

\author{
Ф. М. Исатаева ${ }^{1}$, Г. И. Рудько ${ }^{2}$, В. С. Портнов ${ }^{1}$
}

1 - Карагандинский государственный технический университет, г. Караганда, Республика Казахстан, е-mail: isataeva.farida@gmail.com

2 - Государственная комиссия Украины по запасам полезных ископаемых, г. Киев, Украина, e-mail: rudko@ dkz.gov.ua

Цель. Обоснование экономически целесообразного способа отработки месторождения Кусмурин.

Методика. Анализ литературных и фондовых материалов; исследования физико-механических свойств пород и руд.

Результаты. Для улучшения экономических показателей, снижения себестоимости концентрата на месторождении Кусмурын меняется система отработки. На смену камерно-столбовой системы разработки, позволяющей извлекать все имеющиеся запасы, внедрена более эффективная модель - отработка междукамерных целиков с высоким содержанием металла. Авторами доказана целесообразность отработки открытым способом с использованием системы разработки горизонтальными слоями с закладкой.

Научная новизна. Расчет технико-экономических показателей трех вариантов отработки позволил выбрать наиболее эффективный способ отработки на месторождении Кусмурын. В целях превентивных мер, предотвращающих подземные пожары, рекомендована система слоевого обрушения с заиливанием обрушаемых пород. Для вкрапленных руд применим обычный способ с обрушением налегающих пород.

Практическая значимость. На основе проведенных исследований разработаны рекомендации для корпорации „Казахмыс“. Они касаются уменьшения с 2019 года проведения открытых горных работ на месторождении Кусмурын. Это стабилизирует достигнутый уровень добычи, компенсирует выбывающие функционирующие объекты, связанные с месторождением. Ввод подземной добычи рекомендован с 2021 года.

Ключевые слова: минерально-сырьевая база, медная руда, месторождение Кусмурын, запасы, KAZRC, CRIRSCO

Recommended for publication by A. D. Mausimbaieva. The manuscript was submitted 23.01.19. 